\title{
Art in Pandemic Chaos and Doom
}

\section{Anna Sungkar}

Institut Seni Indonesia Surakarta. (anna_sungkar@yahoo.co.id)

\author{
Abdul Rahmat \\ Gorontalo State University. (abdulrahmat@ung.ac.id)
}

\section{Keywords}

Pandemic, Doom, Virtual, Gallery, Reality, Antithese, Chaos, Carnivalization.

Article Received: 18 October 2020, Revised: 3 November 2020, Accepted: 24 December 2020

It's lonely outside. Quiet pressing and jostle.

Straight trees, stiff. Not moving

Get to the peak. Lonely biting,

There is no power to release and snatch

Everything awaits. Waiting. Waiting.

Quiet.

The longer the wait becomes strangling

Weigh the shoulders, sunken, shrunken

Until everything perishes. It is not a matter

Poisonous air. Satan cheered.

It's lonely all the time. And waiting.

\section{(Chairil Anwar) $^{1}$}

It has been a year since the Covid-19 pandemic has constricted our lives. Art activities that we used to unimpeded and freely carry out are now limited because we can no longer access public activities. Showrooms and galleries are closed, so we can only participate in the exhibition virtually. Likewise, meetings with the arts community can only be done via video conference. In my opinion, that it is not enough for a work of art to be seen only virtually, prospective collectors must see directly on the spot, before deciding to acquire an art work. It also affected the art business as a whole, resulting in limited collection efforts. With that condition,

\footnotetext{
${ }^{1}$ Jassin, HB, 1980, Chairil Anwar Pelopor Angkatan 45, Dian Rakyat, Jakarta, 18.

${ }^{2}$ Sutton, Benjamin, Gallery Sales Dropped 36\% as Art Market Reeled from Pandemic, ART SY, New York, 18 September 2020.
}

the business of selling art came to a standstill, and the artist's life became disrupted. ${ }^{2}$ Even though the pandemic has greatly affected the economic life of artists, we can see artworks continue to be made with great passion, especially artwork inspired by the events of this pandemic.

\section{A Painting of Doom}

I think, we remember Pieter Bruegel the Elder 's painting "The Triumph of Death" (1562-63). The painting shows the scene of a troop of skeletons wreaking havoc on a dark and desolate landscape. Flames burned in the distance, and the sea was filled with wrecks. Some hills have leafless trees, while other hills have no trees at all. Fish rot on the edge of a pond filled with corpses. There was a scorched, barren earth, devoid of any life as far as the eye could see. At the rear, the legions of skeletons moved forward in pursuit of the living, with those being chased running away in fear or trying to fight in vain. In the foreground, skeletons are transporting carts full of skulls. In the upper left corner, another skeleton rings a bell indicating the time of death of the world. People were led into coffin-shaped traps decorated with crosses, while skeletons seated on horses killed people with sickles. $^{3}$

\footnotetext{
${ }^{3}$ Greenberg, Mark, ed., 2005, Symbols and Allegories in Art, The J. Paul Getty Museum, Los Angeles, 84-85.
} 


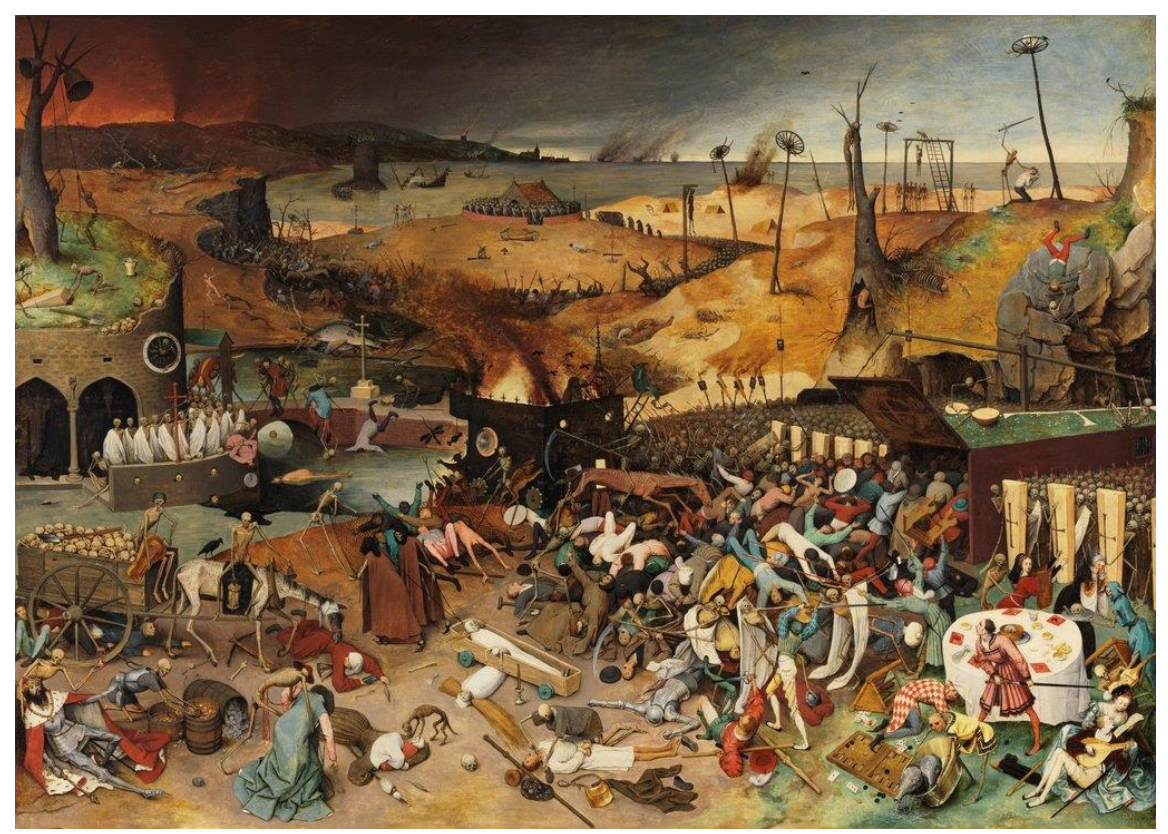

Plate 1- Pieter Bruegel the Elder, "The Triumph of Death" (1562-63).

Pieter's paintings depict people from different social backgrounds - from peasants and soldiers to aristocrats and kings and cardinals - being killed indiscriminately. ${ }^{4}$ If we make an analogy with the present era, don't these frameworks represent an epidemic currently sweeping the world, which does not choose to attack anyone, namely Covid-19?

Pieter Bruegel has managed to send chills down the spine of imagining this terrible event. However, that is what we feel today, when we see the burial place of Covid victims in Pondok Rangon, Jakarta. People dressed in Personal Protective Equipment (PPE), whose entire bodies were covered to prevent infection, carried Covid's coffins to be buried. The cemetery for the Covid victims is now full and the plan is to make it level down. So that one grave hole can contain up to 3 bodies. $^{5}$

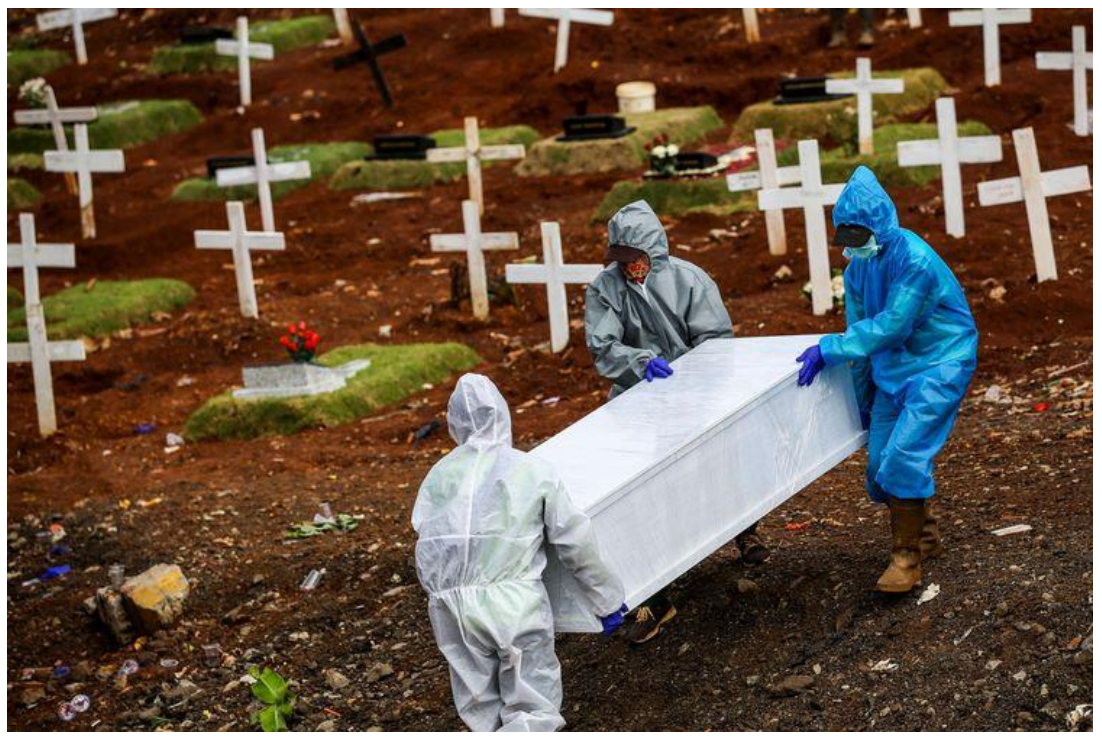

Plate 2 - Funeral officers carrying Covid coffins in Jakarta.

\footnotetext{
${ }^{4}$ Woodward, Richard B., Death Takes No Holiday, The

Wall Street Journal, 14 February, 2009.
}

${ }^{5}$ Kompas, 4 January 2021. 
Thus, fine art can symbolically depict a reality in a artwork. Symbols are created to hide the meaning to be conveyed. But in this day and age, people can be more candid in delivering messages, so that the Covid disaster can be immediately captured by the viewers' meaning and intention. The troubling Covid situation is then digested and described by Indonesian artists, so that through their work, we can find out what they are thinking and feeling.

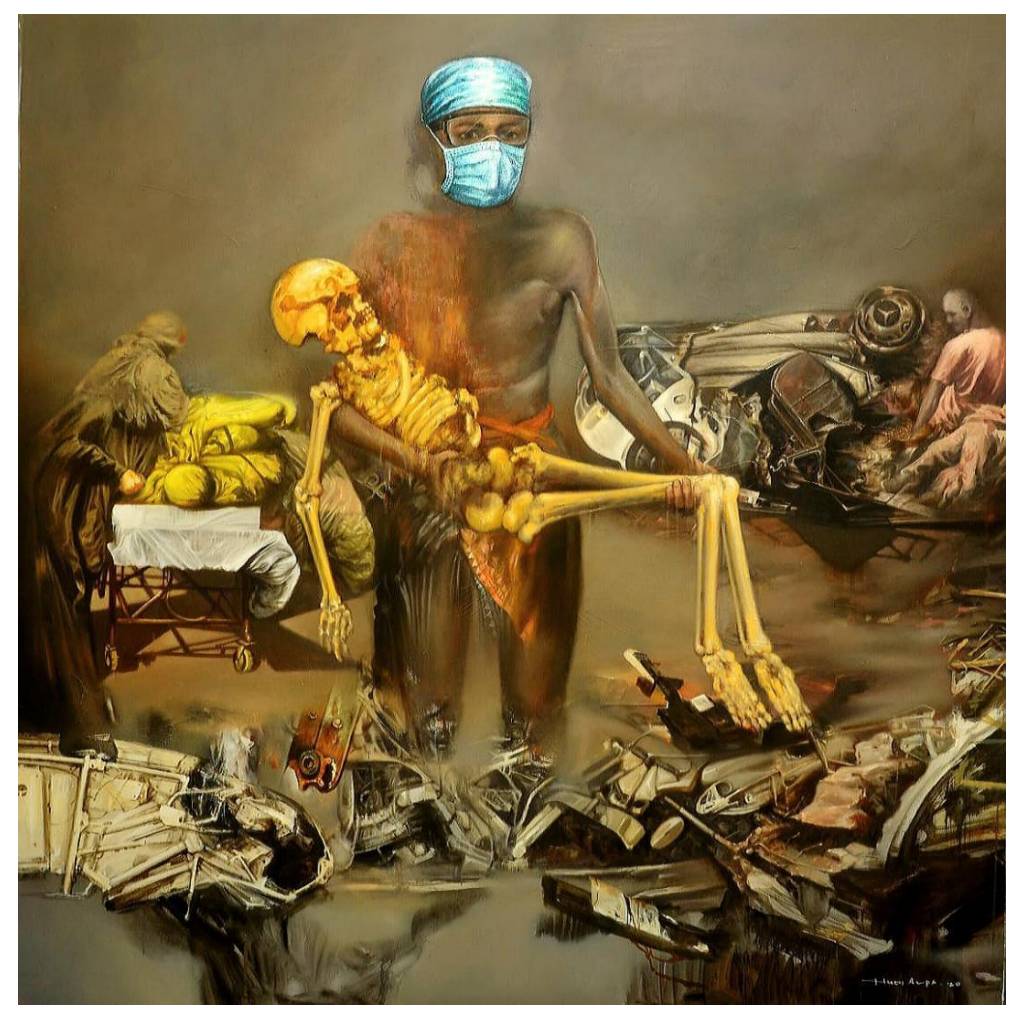

Plate 3 - Hudi Alfa, “Justice for All” (2020).

The following description will depict the works of Indonesian artists whose names are already wellknown at home and abroad, they are seniors in terms of exhibition experience, won fine arts competitions and have achieved commercial success. Sunaryo, for example, is a senior art lecturer at ITB, one of the oldest universities in Indonesia. Gatot Indrajati and Hudi Alfa, are artists who won the art competition of UOB paintings, an international bank that actively organizes art championship events every year.

\section{Justice for All}

Hudi Alfa, who was born in Ngawi, East Java, in 1969, talk about the gripping Covid pandemic. The painting with a brown background depicts death everywhere. On the top left of the painting, we see medical workers treating patients, while on the top right of the picture we see people suffering surrounded by rubble. Victims do not choose race, religion, social status and identity. He entitled his work "Justice for All".

Hudi describes the victim as a skeleton because humans basically have no difference at all from other humans, which in the end all will end up being a skull. People who want to share their help voluntarily do not need to know who they are, because all of their faces are covered with masks and they don't care who helps whom. At last, justice for all. This is reflected in the skull carried by the masked person. When that happens, the victim does not need to be identified from what group. Because anyone is obliged to help the living to survive and help the dead to be processed and buried.

\section{Waiting for Covid to end}

Indeed, we are all waiting for when the Covid disaster will end. Everyone was given a signal from the government to keep their distance, wear masks, wash their hands and stay at home. Mahdi Abdullah 
(born in Aceh, 1960) describes how humans spend time at home with tedious activities in his work entitled "Waiting until Further Notice" (2020). The events in the paintings are symbolic. A person in red PPE was turning a wagon wheel. Mahdi describes a person who plays with pushing the cart wheel as a symbol of humans who are walking through the wheel of time. There is not much that can be done, apart from waiting for time.

Almost the same symbolism in the background, namely the person with the head of a globe holding his mask. Where on the mask there is a hole that shows a tree that symbolizes life. On the globe there is a hotspot originating from a corner of the world map, namely Wuhan - where Covid started. Mahdi uses the people around him as models in paintings. In the foreground is a picture of a pair of teenage children chatting in the middle of the house, and behind the window is a neighbor peeking inside because he is tired of sitting in his own house.

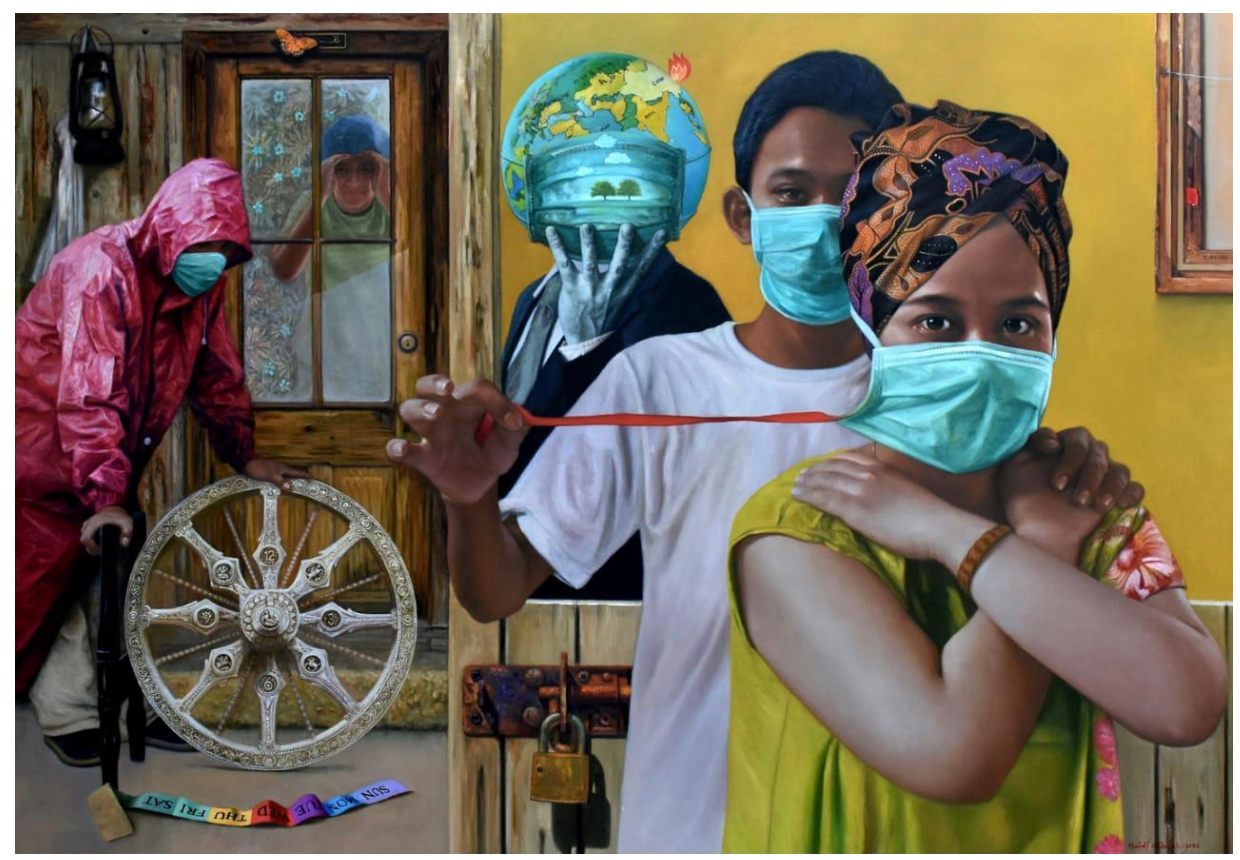

Plate 4 - Mahdi Abdullah, "Waiting until Further Notice" (2020).

\section{Mask dance for God}

Pajegan is a term in Balinese that relates to traditional dances for ceremonies of worshiping God. Dancers in the Pajegan dance always use masks in performing. The Pajegan show is not just entertaining, but full of meaning. Inside, there are many moral lessons that can be taken as a way of life. Sunaryo (born in Banyumas, 1943) created a painting entitled "Pajegan for Hyang Widhi Wasa" (2020).
However, different from the usual mask depiction, Sunaryo replaced the female dancer's mask with a white mask. This is of course related to the current condition of Covid, where with the obligation to wear masks, dancers no longer wear dancing masks, but use health masks for practicality. This painting is made in white shades to symbolize transcendence, purity, cleanliness and peace. On the left we see two arrangements of offerings in honor of God. And hope that Covid will end soon. 


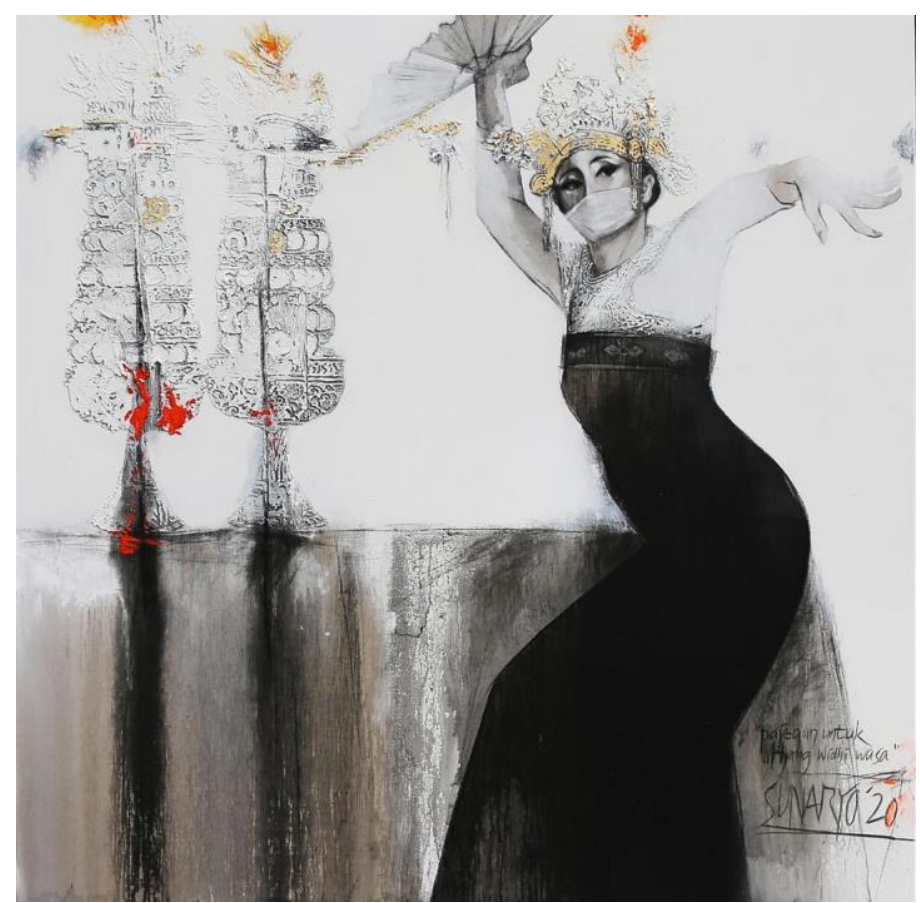

Plate 5 - Sunaryo, "Pajegan untuk Hyang Widhi Wasa" (2020).

Hyang Widhi Wasa is the title of God in Hinduism, which means "He who is unthinkable" or "He who cannot be imagined". We can think about the impact of Covid on our lives, but we cannot imagine when this Covid will end.

\section{Boredom Therapy}

At the end of 2020, the virtual world of Jakarta will be busy with art exhibitions organized by the wellknown art event organizer, Art Jakarta. One of the galleries displayed by Art Jakarta is Art Seasons, a gallery originating from Singapore. Art Seasons featured two painters from Yogyakarta, namely Gatot Indrajati and Nano Warsono. They created a project called Boredom Therapy. ${ }^{6}$

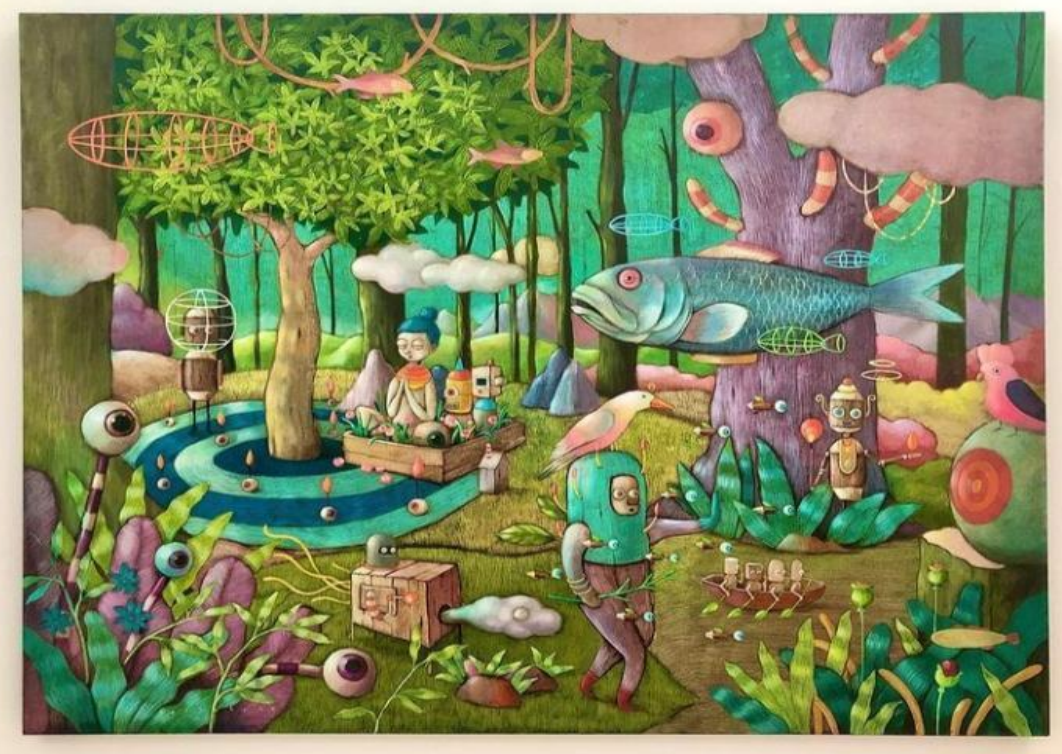

Plate 6 - Gatot Indrajati, “Alprazolam” (2020). 
Boredom Therapy is an activity to get rid of boredom. Because, as explained earlier, artists are less active in holding exhibitions. In the video presented by Art Seasons, Gatot Indrajati (born in Bogor, 1980) said that playing music and gardening - apart from painting - is a way to pass the time as long as it is not advisable to leave the house. For him, art activities are something that should be done during this pandemic because they can increase one's immunity. Gatot made a painting entitled "Alprazolam" (2020), which tells the story of animal life that cannot move freely when confined in a zoo. The same is true of humans. For this reason, Boredom Therapy tries to return to nature, like doing gardening activities earlier. Where activities like this are a form of therapy for disappointment and mental exhaustion due to being confined at home, besides humans are facing uncertainty about when this pandemic will end.

\section{God of Medicine}

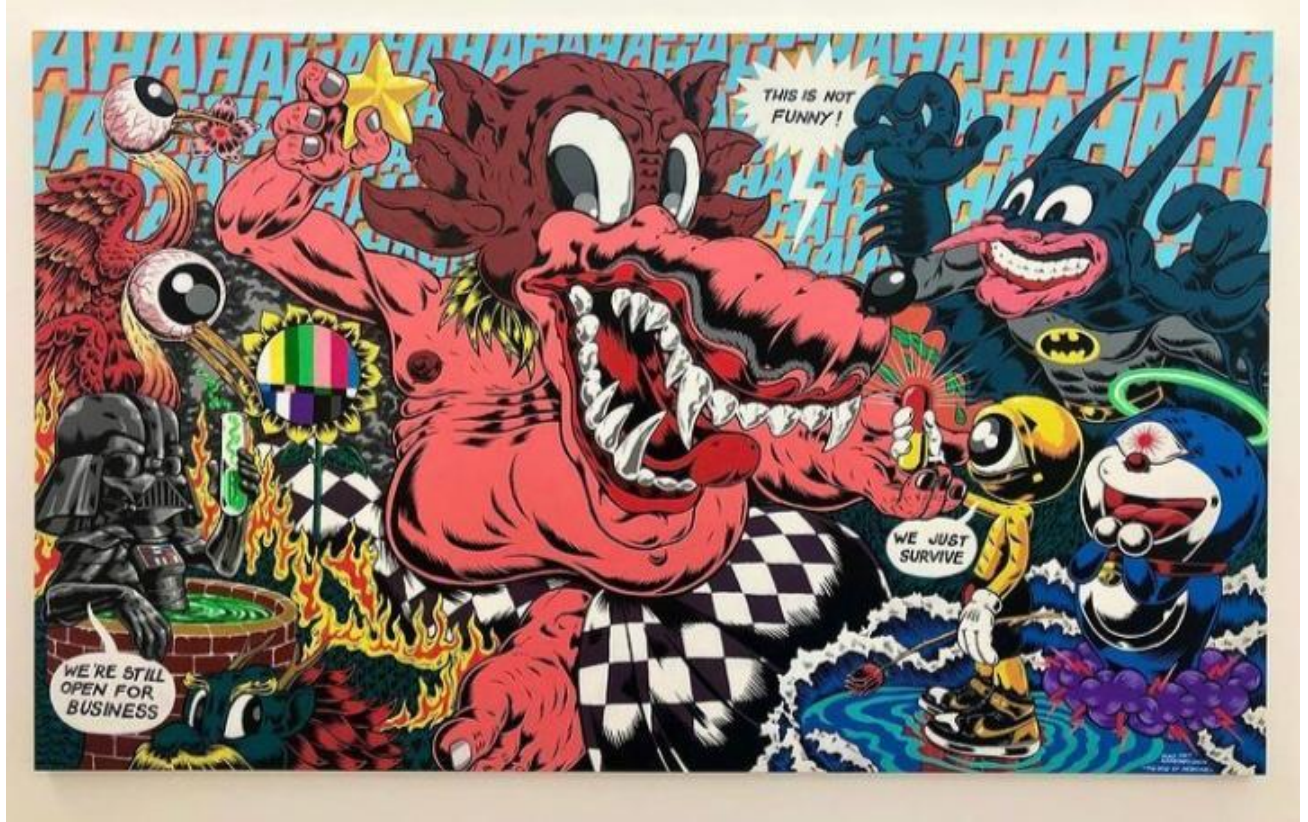

Plate 7 - Nano Warsono, "God of Medicine" (2020).

In the Boredom Therapy project, Nano explores visual ideas based on fictional stories. In the painting entitled "God of Medicine" (2020), he shows fictional characters who usually appear on television, such as Batman, Darth Vader and Dora Emon. In the center of the comic-style painting, we see a red medicinal god in action against fictional characters with evil faces. But why is the crocodile called the god of medicine? Maybe the god of medicine is actually the Covid virus itself. Nano is looking for new forms in the pronunciation of his art, so we see a reversal of form there. The characters who are usually good this time are made evil, in contrast the god of medicine is given the shape of a crocodile.

\section{Should Art describe reality?}

The author wants to ask reflective questions about the ability of Art to express reality. Sometimes, we as art observers want to find the meaning of artwork made in a certain period of time. Can artwork immediately describe reality as it is, exactly with the events that occur? With that reality seems to be accurately reflected in artwork, in this context Art reveals pandemic events.

It seems that the answer is not that simple. So that I want to reopen the old theory that Theodor Adorno introduced more than half a century ago. Adorno argues that we must separate Art from reality, and Art should be the antithesis of society. However, that does not mean that Art is separated 
from its people. ${ }^{7}$ Art must not reduce its portion as part of society, but still be in opposition (antithesis) to society. Artwork can be meaningful if it can criticize. So that art has social value towards the facts of society that is being criticized (art becomes social by its opposition to society). ${ }^{8}$ For Adorno, the autonomy of art means having the function of criticizing society, so that art is freed from having to perform certain predetermined social roles. With the presence of Art as something unique, which only obeys its own laws, the autonomy of Art stands in contradiction to society - that is, a society that wants everything to be economically interchangeable with one another. We can see that the relationship between Art, which according to Adorno must be separated from objective reality, in this case society, is then defined as the antithesis of society. By giving the role that Art is the antithesis of society, Art will become something. Art will exist if it can criticize reality.

However, it does not mean that in its function as the antithesis of society, Art must use an explicit statement as a political opinion. But what is needed is his awareness as art, namely awareness of the reality that occurs in society and at the same time being radically opposed to that reality. Adorno said that Art can express social things in society poetically, not politically. Poetry will thus serve as an example of an established sociological thesis. ${ }^{9}$ Lyrics in poetry, for example, are seen by Adorno as a vehicle that can channel subjective emotional states into social and universal circumstances. This is consistent with his view of the relationship between Art and reality that we find in Adorno's aesthetics. For example, solitude, which is so often emphasized as so important in lyrical poetry, has a social meaning, for such poetry arises from an individualistic society. ${ }^{10}$. What is important, the relationship between Art and society is not built by anything that is stated explicitly, but more than that, namely it takes depth from the work of art in seeing reality.

\footnotetext{
7 Adorno, Theodor, 1997, Aesthetic Theory. terj. HullotKentor, Robert, Continuum, University of Minnesota, 8.

${ }^{8}$ Aesthetic Theory, 225.
}

If so, will the artwork automatically portray the reality of the pandemic that has occurred? In fact, Adorno emphasizes the critical power of art in seeing this pandemic. What critical power is possible in pandemic-related artwork? We will use Adorno's theoretical framework in reading Nano Warsono's "God of Medicine". It's obvious, the Nano's painting is not a representation of reality. There is no human figure in the painting. The Covid virus, which is described in science journals as a thorny circle, is described by Nano as a creature with a crocodile mouth (but Nano calls the crocodile the god of medicine). Likewise, the superheroes who are usually portrayed as fighting crime are seen to be friends with 'the crocodile'. And there is a mix-up between the superhero character played by Batman and Darth Vader, the evil character in the Star Wars story. Likewise, the appearance of Dora Emon, an animated character from Japan who usually has all kinds of science tricks from her magic bag to solving life. Instead, he looks loiter with a yellow one-eyed character holding a 'medicine' capsule. The usually handsome Batman character, this time, has a long nose similar to that of Penguin, his enemy. Is the Batman in Nano's work a bad character?

Nano's painting is an antithesis to reality, where humans are expected to live well and calmly at home, as in Mahdi Abdullah's painting. Nano actually causes disorder in this pandemic, the characters in his paintings create an atmosphere of chaos, this shows that the real reality is not okay like in Mahdi's work. That is what Adorno means that Art is the antithesis of reality, but cannot be separated from reality. Because what Nano wants to describe is still in the context of a pandemic disaster, a reality of events currently taking place in society.

\section{Carnivalization}

In other languages, with more modern terminology, Ella Shohat and Robert Stam introduce the term

\footnotetext{
${ }^{9}$ Adorno, Theodor, 1991, Notes to Literature, vol. 1, terj. Nicholson, Shierry Weber, Columbia University Press, New York, 37-38.

${ }^{10}$ Notes to Literature, 1991, vol 1, 38
} 
Carnivalization, to describe an alternative aesthetic that does not imitate the old traditions of beauty, by radically breaking with the aesthetics of the past. Artwork that creates an aesthetic counterpoint to the old culture through a shocking effect and uses disconcerting juxtapositions. ${ }^{11}$ In Carnival aesthetics, everything is counterintuitive, opposite and contradiction - because it uses an alternative logic that is different from positive rationalism. With the concept of carnivalization, we can then understand the image of the superhero Nano which is anti-Canon and becomes subversive.

The same carnivalization occurs when we see a topless medic with a masked face carrying a skeleton, in Hudi Alfa's work. We can no longer understand the existence of car debris side by side with Covid victims, because positivism can no longer be applied to this painting. Likewise, the fish passing through the forest, in Gatot Indrajati's painting, is something that is misplaced, miscegenated, and completely out of formal harmony.

\section{Summary}

This paper begins with an excerpt from Chairil Anwar's poem entitled "Hampa (Emptiness)". Chairil is an Indonesian avant garde poet who introduces new poetic forms that are free of order. Even though this poem was composed 80 years ago, its content is still relevant to today's situation. Chairil tells about the air is poisonous, the devil is cheering, the waiting is choking, loneliness and emptiness, until we all perish. Imagining this poem while observing the paintings made by Hudi Alfa feels a similar atmosphere, we imagine the devil cheering with the chaos created by Nano Warsono, feels connected. And we capture the loneliness and emptiness reflected in Mahdi Abdullah and Sunaryo's paintings. Although these five paintings by Indonesian artists were made in different styles, we finally caught a common thread: human suffering and hope for an end to the Covid pandemic. This is in line with what Pieter Bruegel

\footnotetext{
${ }^{11}$ Shohat, Ella dan Stam, Robert, 1998, Narrativizing Visual Culture, toward a polycenric aesthetics, dalam Mirzoeff,
}

the Elder had made in the painting "The Triumph of Death".

In reading some of the paintings above, the writer uses Adorno's thinking about art that must be distant from reality, as well as the concept of Carnivalization which can bring us closer to the understanding of the chaos of reality that is happening today. With that, we understand that reality is not all right, behind it there is a threat peeking at humans. And waiting for all of us to find a solution so that our beloved earth can return to peace and be saved from harm.

\section{Reference}

[1] Adorno, Theodor, 1997, Aesthetic Theory. trans. Hullot-Kentor, Robert, Continuum, University of Minnesota.

[2] Adorno, Theodor, 1991, Notes to Literature, vol. 1, trans. Nicholson, Shierry Weber, Columbia University Press, New York.

[3] Greenberg, Mark, ed., 2005, Symbols and Allegories in Art, The J. Paul Getty Museum, Los Angeles.

[4] Jassin, HB, 1980, Chairil Anwar Pelopor Angkatan 45, Dian Rakyat, Jakarta.

[5] Kompas Newspaper, 4 January 2021.

[6] Sutton, Benjamin, Gallery Sales Dropped $36 \%$ as Art Market Reeled from Pandemic, ART SY, New York, 18 September 2020.

[7] Shohat, Ella and Stam, Robert, 1998, Narrativizing Visual Culture, toward a polycenric aesthetics, in Mirzoeff, Nicholas, "The Visual Culture Reader", Routledge, New York.

[8] Woodward, Richard B., Death Takes No Holiday, The Wall Street Journal, 14 February, 2009.

[9] https://www.instagram.com/tv/CHcimeeH $\mathrm{VXh} /$ ?igshid=r2o4n07abn39

\section{Curriculum Vitae}

Nicholas, "The Visual Culture Reader", Routledge, New York, 44-47. 
Anna Sungkar was born in Jakarta, 1960. Taking a Bachelor in Accounting at Trisakti University (1985), and a Bachelor in Arts at the Jakarta Arts Institute (2013), obtained a Masters degree at the Jakarta Arts Institute (2016), and a Doctorate at the Indonesian Art Institute Surakarta (2020). He has worked as an executive in the automotive and petroleum industry. Recently, in fulfilling the necessities of life, she has her own business in the retail sector for consumer products, has become an art dealer and also a curator in art exhibitions in Jakarta.

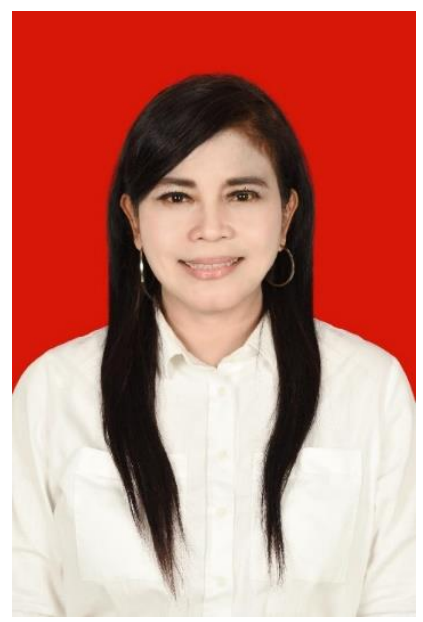

The exhibitions that have been done in the past 3 years are the IKJ Postgraduate Exhibition (2018), the Cirebon Islamic Boarding School Exhibition (2019), the Solo Painting Exhibition of Poor Women in Photo Realism (2020), the Universal Art Paper Exhibition (2020), the Flower in Paper Media Exhibition (2020), Exhibition of Religiosity in Contemporary Art (2020).

Several papers that have been published recently, among others:

- Creation Process of Painting Poor Woman using Photo Realism Technique. International Journal of Arts and Humanities. ISSN: 25813102. Volume: 04, Issue: 04 April 2020. www.journal-ijah.org

- The influence of Western Art Development Towards the Emergence of New Fine Art
Movement in Indonesia. Asian Journal of Social Sciences \& Humanities. ISSN: 21868492. Volume: 9, Issue: Feb-May 2020. www.ajssh.leena-luna.co.jp

- Contemporary Art Stimulate Realism Style Paintings. Visualita, Online Journal for Visual Communication Design. ISSN 2655-2140. Volume: 09, Issue: October 2020.

- Ahmad Sadali the Pioneer of Indonesia Abstract Paintings, in "Various Thought about Arts, Design in Philosophical Analysis and Praxis". ISBN: 978-623-95840-3-0, PACE Solok, Sumatra Barat, 2021. 